\title{
Corrigendum: Abiotic and Human Drivers of Reef Habitat Complexity Throughout the Main Hawailian Islands
}

\author{
Gregory P. Asner*, Nicholas R. Vaughn, Shawna A. Foo, Ethan Shafron, Joseph Heckler \\ and Roberta E. Martin
}

Center for Global Discovery and Conservation Science, Arizona State University, Tempe, AZ, United States

Keywords: bathymetry, coral reef, Hawai' $\mathrm{i}$, imaging spectroscopy, reef structure, rugosity

\section{OPEN ACCESS}

Approved by:

Frontiers Editorial Office,

Frontiers Media SA, Switzerland

${ }^{*}$ Correspondence:

Gregory P. Asner

gregasner@asu.edu

Specialty section:

This article was submitted to

Coral Reef Research,

a section of the journal

Frontiers in Marine Science

Received: 22 February 2021

Accepted: 03 March 2021

Published: 17 March 2021

Citation:

Asner GP, Vaughn NR, Foo SA,

Shafron E, Heckler $J$ and Martin RE

(2021) Corrigendum: Abiotic and

Human Drivers of Reef Habitat

Complexity Throughout the Main

Hawaiian Islands.

Front. Mar. Sci. 8:671048.

doi: 10.3389/fmars.2021.671048

\section{A Corrigendum on}

Abiotic and Human Drivers of Reef Habitat Complexity Throughout the Main Hawaiian Islands

by Asner, G. P., Vaughn, N. R., Foo, S. A., Shafron, E., Heckler, J., and Martin, R. E. (2021). Front. Mar. Sci. 8:631842. doi: 10.3389/fmars.2021.631842

Ethan Shafron was not included as an author in the published article. The corrected Author Contributions Statement appears below.

The authors apologize for this error and state that this does not change the scientific conclusions of the article in any way. The original article has been updated.

\section{AUTHOR CONTRIBUTIONS}

GA conceived and funded the study, collected the data, provided the analysis, and wrote the manuscript. NV and $\mathrm{JH}$ collected the data, provided the analysis, and contributed to the writing of the manuscript. SF, ES, and RM provided the analysis and contributed to the writing of the manuscript. All authors contributed to the article and approved the submitted version.

Copyright (C) 2021 Asner, Vaughn, Foo, Shafron, Heckler and Martin. This is an open-access article distributed under the terms of the Creative Commons Attribution License (CC BY). The use, distribution or reproduction in other forums is permitted, provided the original author(s) and the copyright owner(s) are credited and that the original publication in this journal is cited, in accordance with accepted academic practice. No use, distribution or reproduction is permitted which does not comply with these terms. 